Original Research Paper

\title{
Sistem Temujanji Interaktif Berasaskan Web
}

\author{
Noor Anida Zaria Mohd Noor ${ }^{1}$, Nurul Haziqah Hasbullah ${ }^{1}$ \\ ${ }^{1}$ Fakulti Seni, Komputeran dan Industri Kreatif, Universiti Pendidikan Sultan Idris, \\ Malaysia.
}

Article history
Received:
16.09 .2020

Revised:

12.11.2020

Accepted:

22.11.2020

*Corresponding Author:

Noor Anida Zaria Mohd Noor Email:

anidazaria@fskik.upsi.edu.my

This is an open access article, licensed under: $\mathrm{CC}-\mathrm{BY}-\mathrm{SA}$

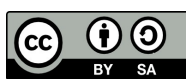

Abstrak: Kajian ini menghasilkan sistem berasaskan web yang bertujuan untuk memudahkan penepatan temujanji bagi pensyarah Jabatan Komputeran, Fakulti Seni, Komputeran dan Industri Kreatif dan pelajar program Kejuruteraan Perisian (AC10) yang dikenali sebagai AC10 Appointment System. Tujuan utama pembangunan sistem ini adalah untuk memudahkan pelajar membuat temujanji dengan pensyarah dengan lebih teratur dan tersusun disamping memudahkan urusan pensyarah menerima termujanji yang akan dibuat oleh pelajar. Sistem ini telah dibangunkan dengan menggunakan metodologi prototaip. Instrumen soal selidik telah digunakan untuk menguji fungsi dan kebolehgunaan AC10 Appointment System. Seramai 20 orang pelajar dari program Kejuruteraan Perisian telah dipilih sebagai respondent untuk kajian ini. Hasil kajian ini mendapati bahawa sistem berasaskan web AC10 Appointment System diterima dengan baik dan berharap sistem ini dapat digunakan bagi memudahkan urusan membut temujanji di antara pensyarah dan pelajar.

Kata Kunci: Sistem Berasaskan Web, Temujanji Interaktif, Prototaip.

\section{Web-Based Interactive Appoinment System}

Abstract: This study produces a web-based system that aims to facilitate appointment planning for lecturers of the Department of Computer, Faculty of Arts, Computers and Creative Industry and students of Software Engineering program (AC10) known as AC10 Appointment System. The main purpose of the development of this system is to facilitate students to make appointments with lecturers in a more organized and organized while facilitating the affairs of lecturers to accept the promises that will be made by students. This system was developed using a prototype methodology. Questionnaire instruments were used to test the functionality and usability of the AC10 Appointment System. A total of 20 students from the Software Engineering program were selected as respondents for this study. The results of this study found that the web-based system AC10 Appointment System was well received and hoped that this system could be used to facilitate the appointment of lecturers and students.

Keywords: Interantive Appoinment, Prototype, Web based System. 


\section{Pendahuluan}

Sistem maklumat web atau sistem berasaskan web merupakan sistem maklumat yang menggunakan teknologi web internet untuk menyampaikan maklumat dan perkhidmatan kepada pengguna atau aplikasi maklumat lain [1]. Ia adalah sistem perisian yang bertujuan untuk menerbit dan menyelenggara data. Sistem maklumat web menyediakan capaian kepada sistem perisian menggunakan komputer dan sambungan internet [2].

Sistem maklumat web menjadi suatu alat atau medium yang sangat penting untuk digunakan di semua peringkat di sekolah, universiti mahupun dalam sektor pekerjaan. Sistem maklumat web digunakan untuk memudahkan prosedur manual yang digunakan sebelum ini supaya sistem tersebut menjadi lebih sistematik dan mudah digunakan [3], [4]. Di mana, selaras dengan perkembangan teknologi yang pesat, dalam kehidupan seharian, maka kita memerlukan pengurusan yang sistematik bagi melancarkan segala urusan. Oleh itu, satu cadangan inovasi mengenai proses penetapan temujanji bagi menggantikan sistem berkonsepkan konvensional kepada modenisasi teknologi telah dibuat bagi menjadikan urusan penetapan temujanji lebih mudah.

Lazimnya, proses penetapan temujanji di antara pelajar dan pensyarah di Jabatan Komputeran, Fakulti Seni, Komputeran dan Industri Kreatif, Universiti Pendidikan Sultan Idris dilakukan secara manual dan telah menimbulkan pelbagai masalah di kalangan pelajar dan pensyarah.

Dari sudut pensyarah, mereka menerima lambakan pesanan ringkas (SMS), whatsapps ataupun emel dari pelajar yang akan mengganggu urusan lain pensyarah. Pensyarah juga berkemungkinan terlepas pandang permohonan temujanji yang dihantar oleh pelajar melalui kaedah yang sedia ada.

Dari sudut pelajar, mereka menghadapi masalah ketiadaan pensyarah dipejabat atau pertindihan waktu dengan pelajar lain kerana mereka tidak membuat temujanji terlebih dahulu.

\section{Kajian Literatur}

Pada kebiasaannya, temujanji dilakukan dengan penjadual dengan menggunakan panggilan telefon atau secara bersemuka. Kaedah ini adalah berdasarkan komunikasi secara verbal dengan orang yang sebenar and membolehkan flexibiliti yang maksimum di dalam situasi yang kompleks [5,6]. Walau bagaimanapun, kaedah tradisional ini memerlukan perjumpaan secara bersemuka atau komunikasi secara lisan dengan penjadual, maka keupayaan untuk mendapatkan persetujuan dengan segera adalah sukar [7], [8], [9].

Disebabkan kelemahan di atas dan seiring dengan era maklumat sekarang, perubahan yang pantas dalam teknologi maklumat dan kamunikasi (ICT) telah menjadi kebiasaan, di mana alatan dan bahanbahan yang digunakan sekarang akan sentiasa diperbaiki dan dipertingkatkan kebolehan serta keupayaannya [10]. Faktor ini telah menjadikan aplikasi ICT tidak dapat dielakkan dan telah digunakan secara meluas dalam hampir semua bidang kehidupan manusia.

\section{Metodologi}

Metodologi pembangunan sistem prototaip [5], [11], [12] telah digunakan untuk membangunkan sistem ini, di mana ianya melalui lima fasa berikut:

- Fasa yang pertama adalah fasa perancangan, di mana aktiviti mengenalpasti kekuatan serta permasalahan penetapan temujanji yang sedia ada secara manual telah dilakukan dengan kaedah pemerhatian dan temubual secara tidak formal.

- Seterusnya diikuti dengan fasa analisis. Pada fasa ini, semua maklumat yang diperolehi dari fasa pertama akan dikumpulkan dan dianalisa secara terperinci supaya bersesuaian dengan objektif aplikasi sistem yang dibangunkan [13]. Rajah 1 menunjukkan aktiviti yang dilakukan oleh setiap pengguna untuk sistem ini.

- Rekabentuk antaramuka pengguna dan pangkalan data telah dihasilkan pada fasa ketiga (fasa rekabentuk) berdasarkan kepada spesifikasi yang telah diperolehi daripada fasa analisis.

- Fasa yang keempat adalah fasa pembangunan prototaip untuk antaramuka dan pangkalan data. Proses pengulangan kepada fasa-fasa analisa dan rekabentuk berlaku setelah prototaip aplikasi diuji oleh pembangun dan para pengguna sekiranya terdapat sebarang kelemahan dan kekurangan dalam aplikasi ini [14], [15]. Proses ini akan berulang sehingga aplikasi ini dapat berfungsi dengan lancar dan diterima.

- Fasa yang terakhir adalah pelaksanaan dan pengujian, di mana sistem ini melalui dua fasa pengujian iaitu ujian kotak putih dan ujian kotak hitam. Ujian kotak putih telah dilakukan oleh dengan menekankan berkaitan dengan sistem logik, dari segi pengekodan logik atau 
tidak. Sementara itu, pengujian kotak hitam telah dilakukan oleh pengguna untuk memastikan sama ada fungsi sistem adalah mencapai matlamat sistem [16].

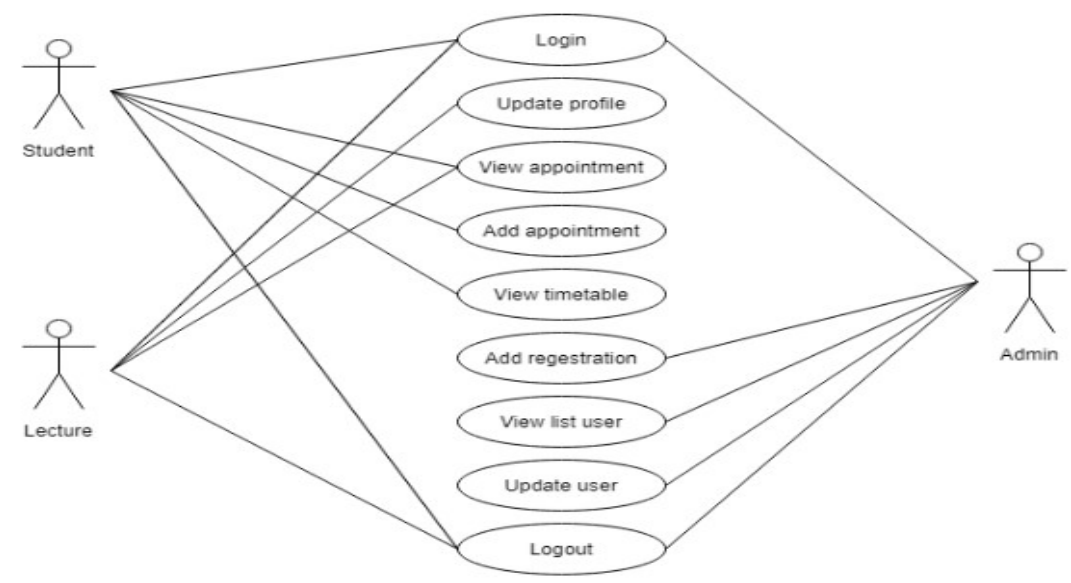

Rajah 1. Gambarajah Use Case

\section{Pembangunan}

AC10 Appointment System ini dibangunkan dengan mempunyai tiga modul pengguna yang berbeza iaitu Pelajar (Student), Pensyarah (Lecturer) dan Pentadbir (Admin).

Rajah 2a menununjukan antaramuka untuk pelajar untuk log masuk ke dalam sisten dengan id dan katalaluan pelajar yang sah. Setelah log masuk berjaya, antaramuka pada Rajah $2 \mathrm{~b}$ akan dipaparkan. Pada antaramuka ini, terdapat beberapa butang fungsi utama. Di antara butang fungsi tersebut ialah butang Home yang berfungsi ntuk kembali ke halaman utama, butang Add Appointment digunakan untuk ke halaman membuat temujanji, butang View Appointment akan ke halaman menunjukkan butiran temujanji. Butang View Appointment membolehkan pelajar melihat jadual yang telah dimuat naik oleh pensyarah sebagai rujukan sebelum membuat sesuatu temujanji dan butang terakhir ialah log keluar yang membolehkan pelajar keluar dari sistem.

Rajah 2c merupakan antaramuka Add Appointment yang digunakan utuk membuat temujanji dengan mengisi maklumat berkaitan dengan nama pensyarah, tarikh, hari, masa, tempat serta tujuan temujanji

Rajah 2d adalah antaramuka View Appointment yang akan menunjukan butiran permohonan pelajar, dimana keputusan permohonan akan dipaparkan pada antaramuka di rajah 2e.

Rajah 2f menunjukan antaramuka View Timetable Lecturer yang akan memaparkan jadual kelas pensyarah sebagai rujukan pelajar sebelum membuat sesuatu temujanji.

Rajah 3a menunjukkan log masuk pensyarah ke dalam sistem dengan mengunakan id dan katalaluan yang sah. Setelah log masuk berjaya, maka antaramuka halaman utama seperti yang dipaparkan pada Rajah $3 \mathrm{~b}$ akan dipaparkan. Terdapat beberapa butang berfungsi pada antaramuka ini, iaitu butang Update Profile untuk ke halaman mengemaskini maklumat pensyarah, butang View Appointment untuk pensyarah menyemak temujanji yang telah dihantar, dan butang log keluar untuk keluar dari sistem.

Rajah 3c menunjukkan antaramuka Update Profile. Di antaramuka ini, terdapat butang update yang boleh digunakan utk mengemaskini maklumat pensyarah yang seterusnya akan dihubungkan ke antaramuka seperti yang dipaparkan pada Rajah 3d, di mana pensyarah perlu mengisi tempat kosong yang disediakan. Dalam antaramuka ini juga terdapat ruangan dimana pensyarah dapat memuat naik jadual kelas pensyarah sebagai rujukan pelajar sebelum membuat sesuatu temujanji.

Rajah 3e menunjukkan antaramuka View Appointment yang akan memaparkan temujanji yang telah dibuat oleh pelajar, di mana pensyarah boleh memaklumkan kepada pelajar bahawa mereka menerima atau menolak temujanji dengan memberikan maklumat berkaitan dengan tarikh, hari, masa dan tempat sekiranya temujanji diterima, serta memberikan ulasan sekiranya temujanji tidak diterima seperti yang dipaparkan pada rajah $3 \mathrm{f}$ dan $3 \mathrm{~g}$. 
Rajah 3h pula menunjukkan antaramuka bahawa pensyarah telah mengemaskini info mengenai temujanji yang telah dipohon dan ianya akan diterima oleh pelajar.

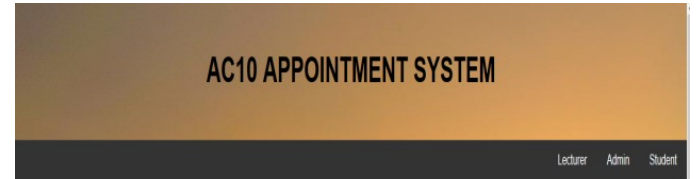

LOGIN FORM

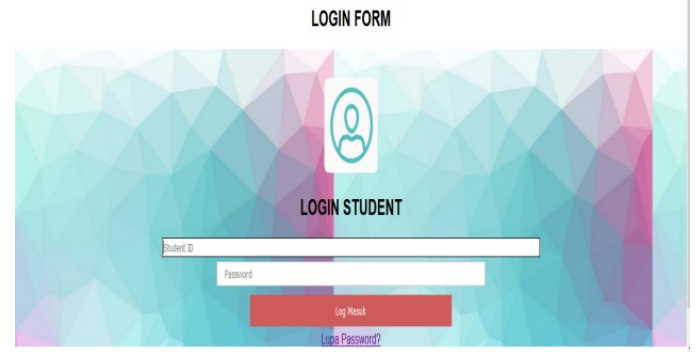

(a)

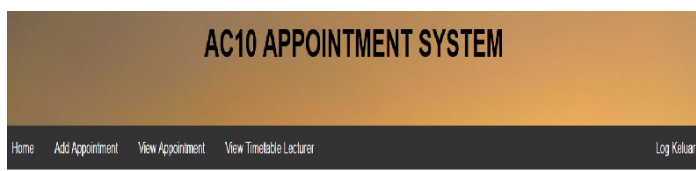

ADDAPPOINTMENT

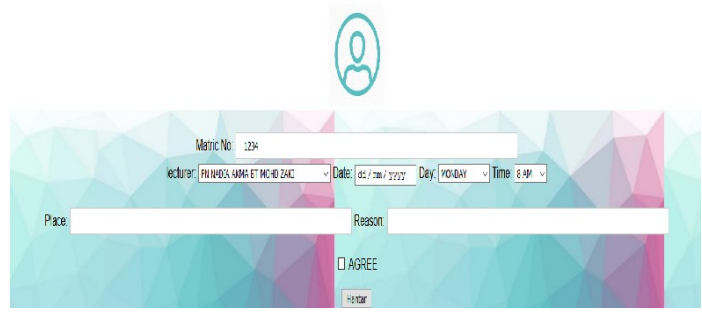

(c)

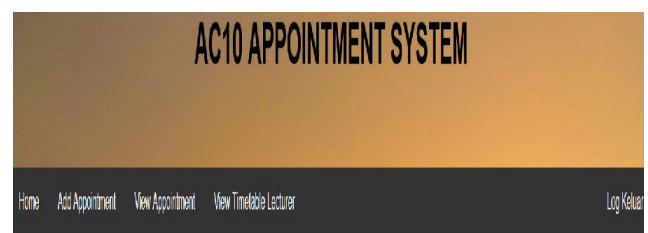

Weloume'1214

STRIISAPPOWWENT

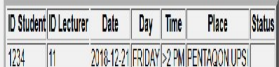

(e)

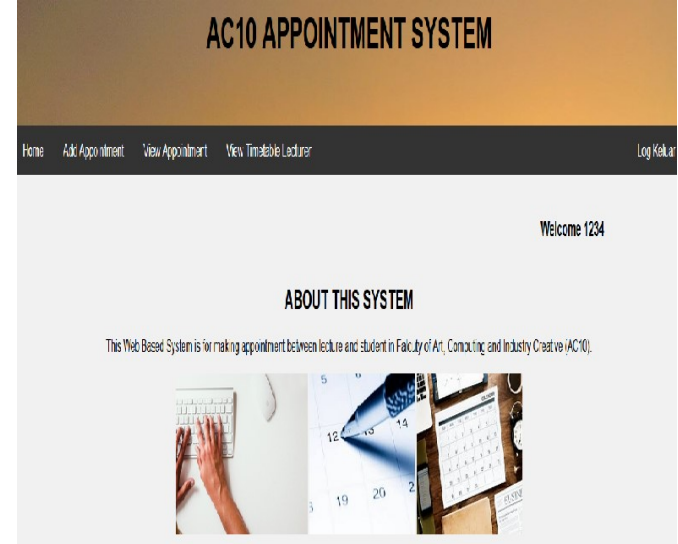

(b)

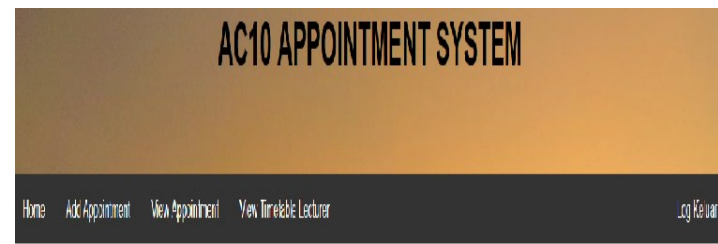

Welcume11

STANSSAPONWWENT

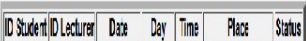

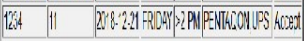

(d)

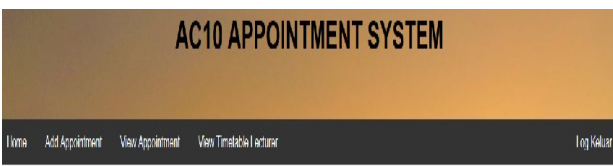

Welame 1234

TIMETABLE LECTURER

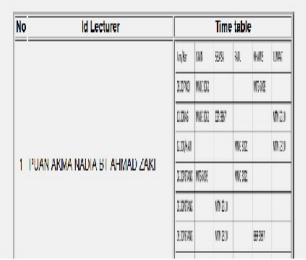

(f)

Rajah 2. Antaramuka untuk Modul Pelajar 


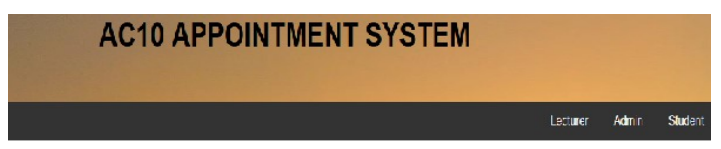

LOGIN FORM

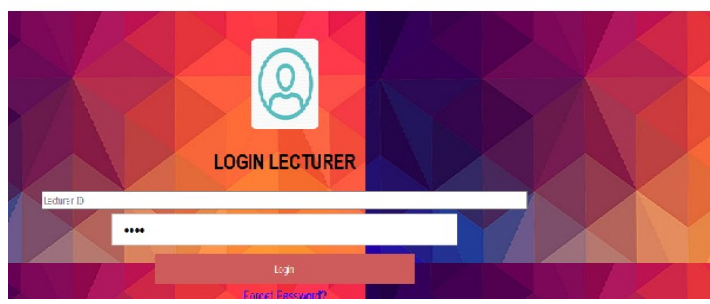

(a)

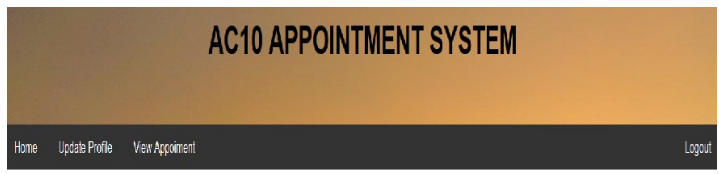

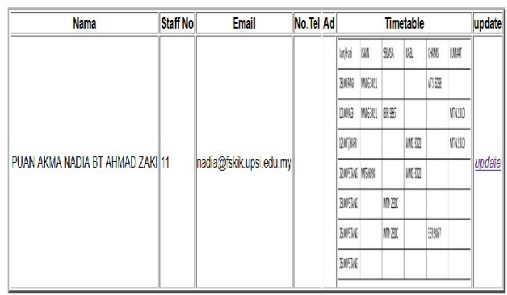

(c)

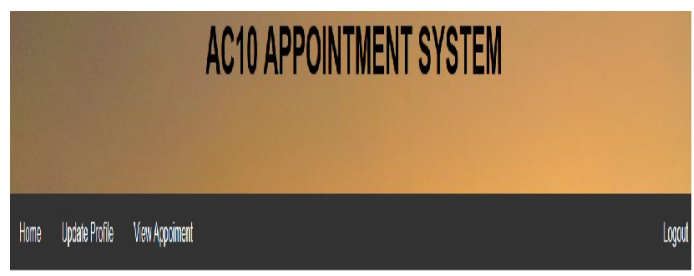

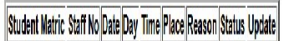

(e)

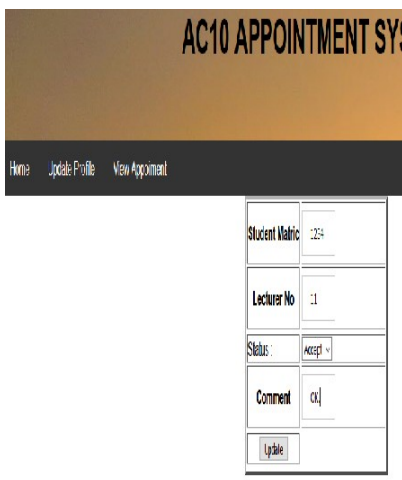

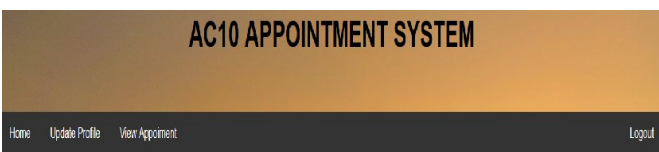

Welcome PUAN AKMA NADIA BT AHMADZZAK

ABOUT THIS SYSTEM

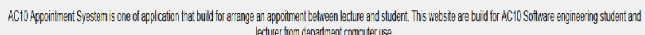

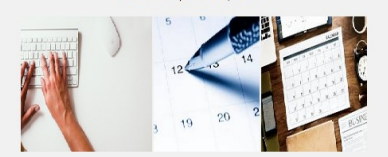

(b)

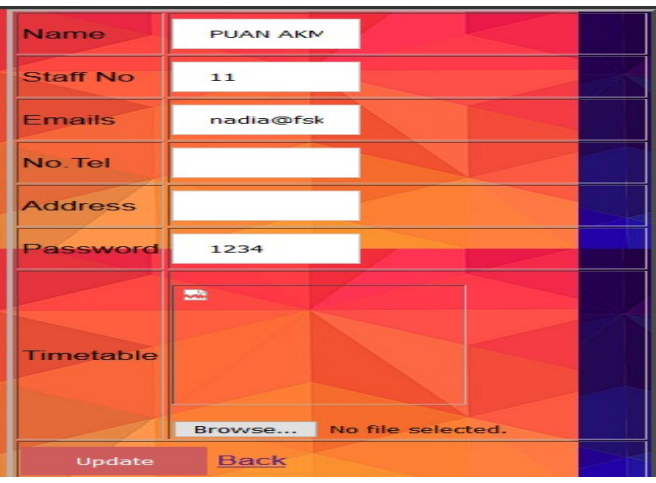

(d)

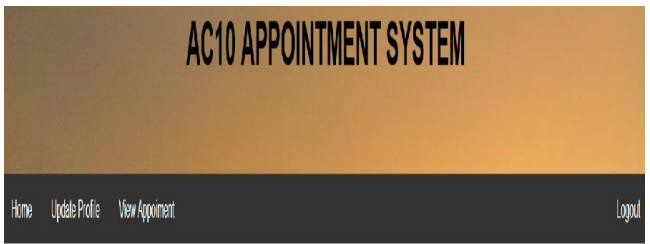

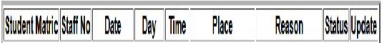

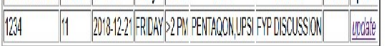

(f)
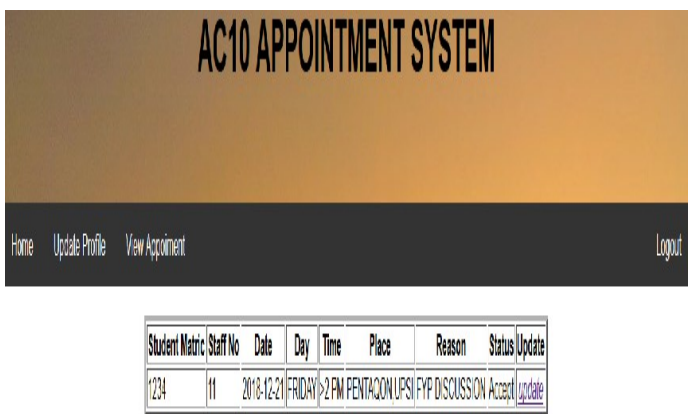

(h)

(g)

Rajah 3. Antaramuka untuk Modul Pensyarah 


\section{Penilaian}

Statistik yang digunakan dalam kajian ialah statistik diskriptif di mana semua data yang diperolehi telah dianalisis menggunakan Mirosof Excell. Alat pengukur bagi kajian ini ialah borang soalselidik (Rajah 5). Borang ini mengandungi dua bahagian iaitu fungsi dan kebolehgunaan. 20 orang responden merupakan pelajar Kejuruteraan Perisian (AC10) di pilih untuk menjawab soalan kaji selidik ini. Soalselidik ini bertujuan melihat sejauh mana AC10 Appointment System ini berguna kepada pengguna. Responden juga perlu menjawab soal selidik berdasarkan penilaian mata seperti skala yang telah ditetapkan.

Jadual 1. Borang Soal Selidik

SoalSelidik dari segi fungsi dan kebolehgunaan.

Jawap soalan berikut menggunakan skala yang telah ditetapkan.

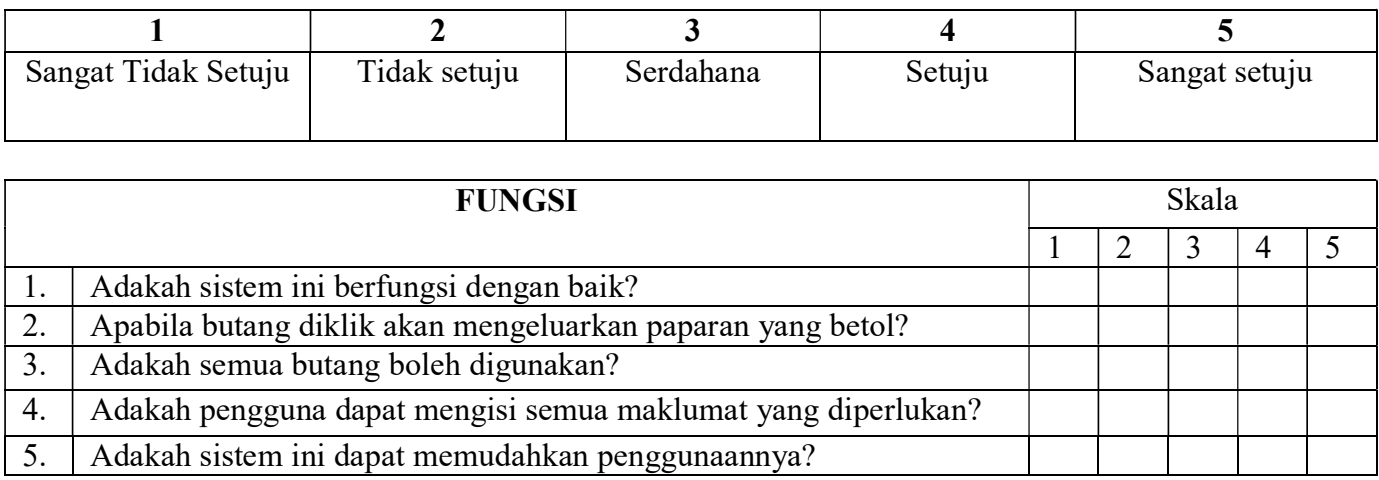

\begin{tabular}{|l|l|l|l|l|l|l|}
\hline \multicolumn{2}{|c|}{ KEBOLEHGUNAAN } & \multicolumn{3}{c|}{ Skala } \\
\cline { 3 - 6 } & 1 & 2 & 3 & 4 & 5 \\
\hline 1. & Adakah saiz dan jenis tulisan yang digunakan bersesuaian? & & & & & \\
\hline 2. & Adakah sistem ini mesra pengguna? & & & & & \\
\hline 3. & Pengguna dapat login di halaman yang betul? & & & & & \\
\hline 4. & Pengguna dapat logout? & & & & & \\
\hline 5. & Adakah antara muka sistem ini mudah difahami? & & & & \\
\hline
\end{tabular}

Graf pada Rajah 4 menunjukkan 70\% daripada respondent bersetuju bahawa sistem yang dibangunkan dapat berfungsi dengan baik (soalan 1). Untuk soalan 2 pula, $50 \%$ respondent sangat bersetuju bahawa butang pada sistem ini menunjukan paparan yang betol. Manakala, hasil daripada soalan 3, seramai $60 \%$ peratus setuju bahawa butang pada sistem ini boleh digunakan dengan baik. Soalan4 menunjukkan $45 \%$ respondent bersetuju bahawa sistem ini pengguna dapat mengisi maklumat yang perlukan. Soalan terakhir bagi soal selidik dari segi fungsi ialah adakah sistem ini dapat memudahkan penggunaannya menunjukan seramai $50 \%$ sangat bersetuju dan bersejutu. Berdasarkan hasil dari soal selidik ini, dapat disimpulkan bahawa kebanyakkan pengguna bersetuju bahawa sistem ini mempunyai fungsi yang baik.

Rajah 5 menunjukkan graf hasil dari soalselidik mengenai kebolehgunaan sistem AC10 Appointment System ini. Berdasarkan soalan 1 dan 2 iaitu adakah saiz dan jenis tulisan yang digunakan bersesuaian dan adakah sistem ini mesra pengguna, hanya 30\% sangat bersetuju bahawa saiz dan tulisan yang digunakan sangat sesuai dan mempunyai sistem yang mesra pengguna. Manakala untuk Soalan 3, berkaitan dengan pengguna dapat login dihalaman yang betol menunjukan seramai $60 \%$ sangat bersetuju. $40 \%$ daripada respondent sangat bersetuju bahawa mereka dapat logout (berdsarkan soalan 4 . Soalan terakhir $40 \%$ memilih skala serdahana bahawa sistem ini mempunyai antara muka yang mudah difahami. 


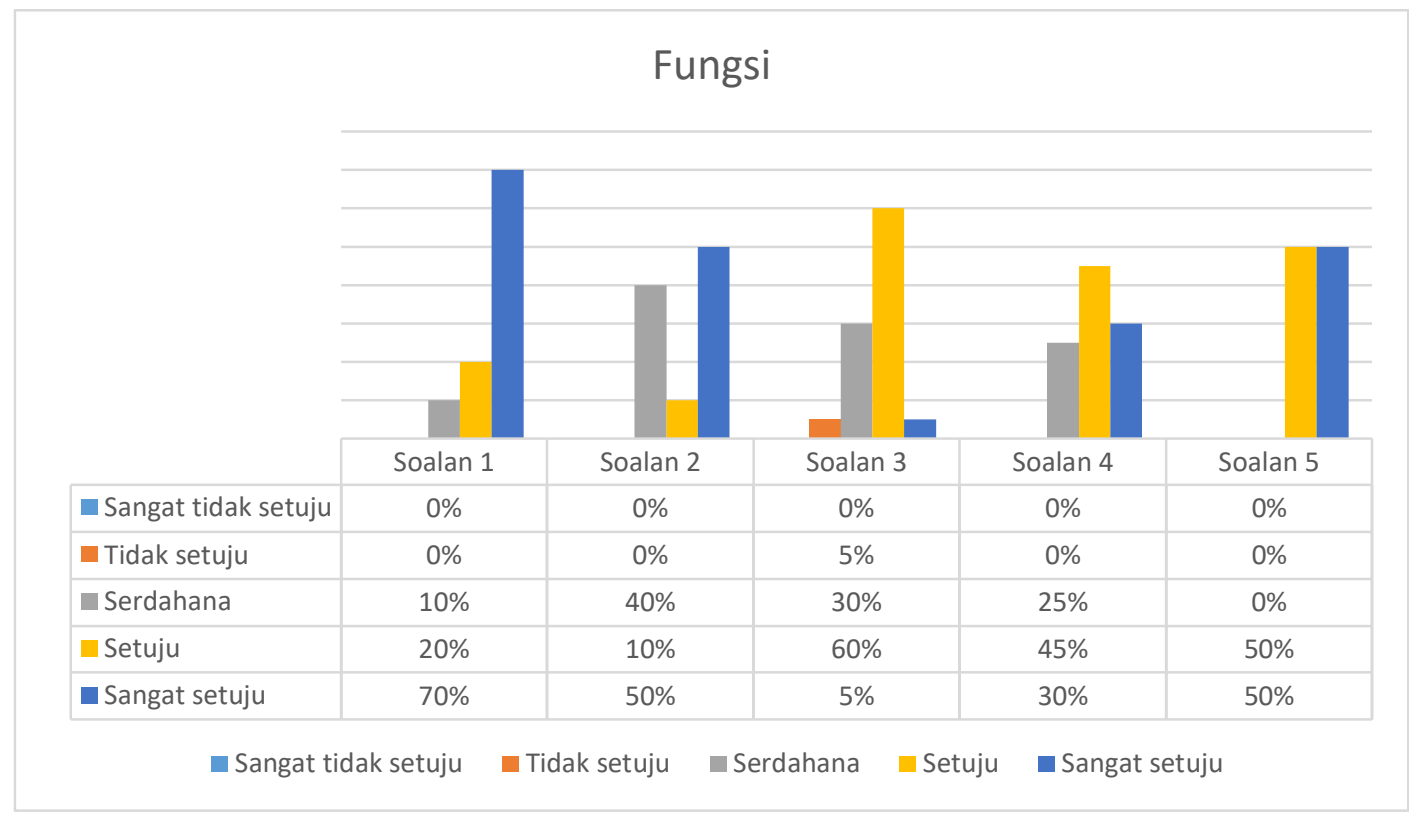

Rajah 4. Kefungsian Sistem

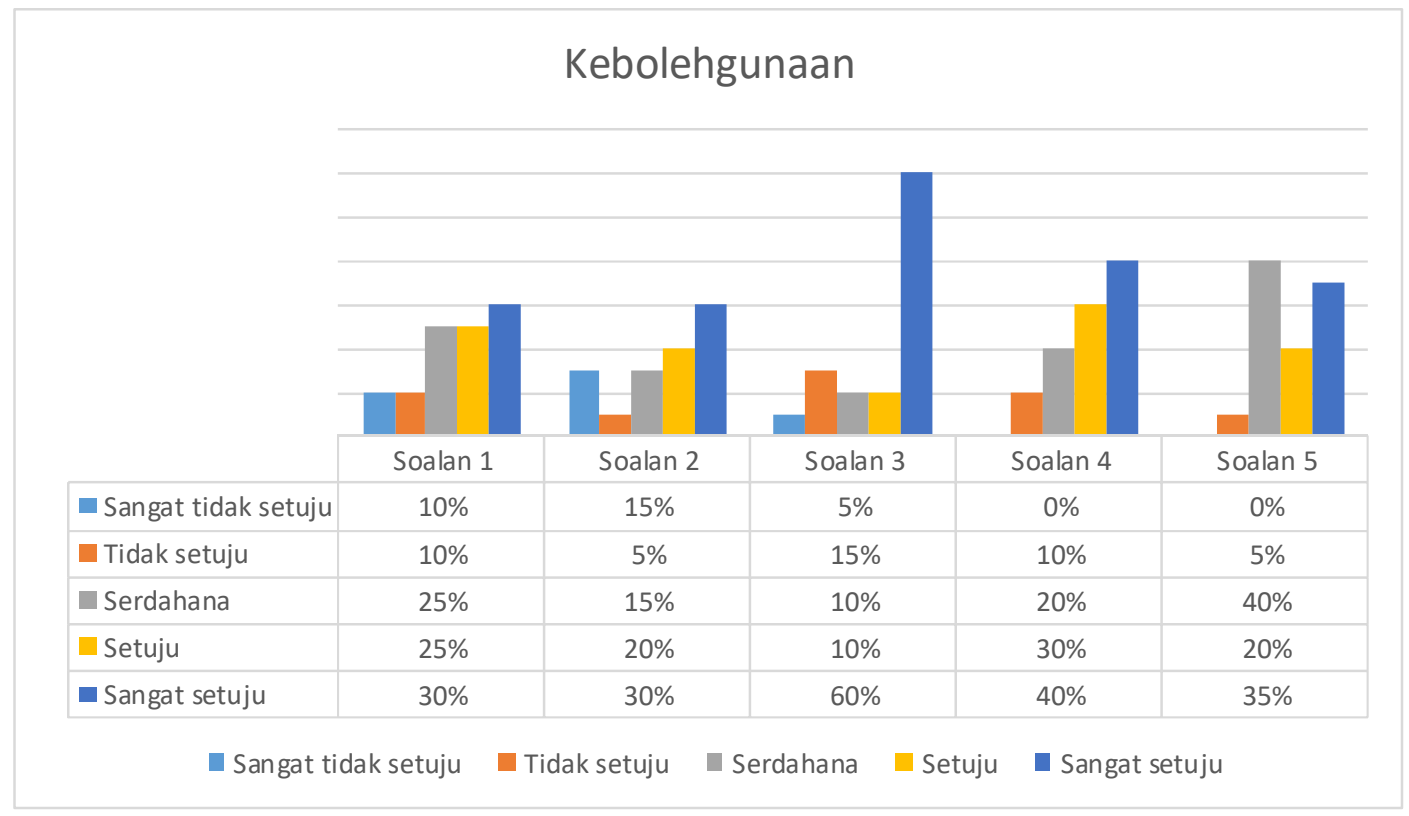

Rajah 5. Kebolehgunaan Sistem

\section{Kesimpulan}

Kepentingan projek ini adalah untuk membantu pensyarah dan pelajar, di mana sistem berasaskan maklumat ini dibangunkan khas bertujuan membantu menyelesaikan masalah yang wujud di dalam program Kejuruteraan Perisian (Perisian Pendidikan) dalam membuat temujanji antara pelajar dan pensyarah.

Dengan adanya sistem berasaskan maklumat ini dapat membantu pelajar membuat temujanji bersama pensyarah. Membantu pelajar untuk mendapatkan maklumbalas segera daripada pensyarah mengenai temujanji tersebut. Seterusnya, membantu pensyarah untuk lebih mudah menerima 
temujanji daripada pelajar.

Dengan adanya sistem ini, dicadangkan untuk membuat penambahbaikan lagi proses membuat temujanji yang berbentuk manual kepada berbentuk sistem yang berasaskan maklumat yang lebih efisyen dan fleksibel. Oleh itu, hasil daripada pelaksanaan sistem berasaskan maklumat ini dapat memberikan kemudahan dalam menguruskan pengaturan penjadualan temujanji antara pelajar dan pensyarah yang lebih sistematik.

\section{Rujukan}

[1] Arora, Web based digital resources and services. Trends and Innovations: Caliber, 2001.

[2] A. Chaffee, What is a web application?. ComputerWorld Magazine, 2000.

[3] Yulianti, and Normalisa, "Implementasi Arsitektur Client-Server dan Model-View-Controller untuk Membangun Aplikasi Administrasi di SMK Averus Jakarta," Journal of Engineering, Technology, and Applied Science, vol. 2, no. 1, pp. 1-18, 2020. doi.org/10.36079/lamintang. jetas-0201.91

[4] A. Fatoni, Normalisa, and A. F. Zulfikar, "Merancang Sistem Aplikasi Pendaftaran Kartu Kredit di Bank Panin Kantor Kas Permata Taman Palem," Journal of Engineering, Technology, and Applied Science, vol. 2, no. 1, 59-85. 2020. doi.org/10.36079/lamintang.jetas-0201.95

[5] Peng-zhoa, "Web-based medical appointment system: a systematic review," Journal of Medical Internet Research, vol. 19, no. 4, 2017. ISSN: 1438-8871

[6] N. F. Z. Zakaria, Z. Zainal Abidin, M. A. Abdullah Zawawi, and S. N. Shuhada, "Bloodbuddy: a Tracking System for Blood Donor Using GPS”, jetas, vol. 2, no. 2, pp. 86-102, Aug. 2020.

[7] X. Zhang, P. Yu, and J. Yan, Patients' adoption of the e-appointment scheduling service: a case study in primary healthcare. Stud Health Technol Inform, 2014.

[8] C. Anwar., and J. Riyanto, "Perancangan Sistem Informasi Human Resources Development Pada PT. Semacom Integrated", ijeste, vol. 2, no. 1, pp. 19 - 38, Jun. 2019.

[9] A. Suganda, R. Dwiputri Permatasari, Pratiwi, and I. Y. Panessai, "Sistem Informasi Pemantauan Retribusi Pada Menara Telekomunikasi," International Journal of Education, Science, Technology, and Engineering, vol. 2, no. 2, pp. 97-111, 2019. doi: 10.36079/ lamintang.ijeste-0202.27

[10] R. Jones, A. Menon-Johansson, A.M. Waters, A.K. Sullivan "eTriage - a novel, web-based triage and booking service: enabling timely access to sexual health clinics," Int J STD AIDS, vol. 21, no. 1, pp. 30-33, 2010. doi:10.1258/ijsa.2008.008466.

[11] F. D. Putra, J. Riyanto, and A. F. Zulfikar, "Rancang Bangun Sistem Informasi Manajemen Aset pada Universitas Pamulang Berbasis WEB”, jetas, vol. 2, no. 1, pp. 32-50, Apr. 2020.

[12] A. Herdiyanto and N. normalisa, "Perancangan Sistem Informasi Akademik SMPN I Tajurhalang”, jetas, vol. 1, no. 1, pp. 1-18, Apr. 2020.

[13] W. Wang, and D. Gupta "Adaptive appointment systems with patient preferences," Manuf Serv Oper Manag, vol. 13, no. 3, pp. 373-389, 2011. doi:10.1287/msom.1110.0332.

[14] R. Wijayanti, and S. Mulyati, "Rancangan Bangun Sistem Informasi Pemantauan Produksi dan Kegiatan antar Divisi”, ijeste, vol. 1, no. 1, pp. 1-14, Dec. 2018.

[15] M. Yorulmaz, H. G. Yavuzcan, and A. Togay, "A web-based management system and its application for studeng design projects," Journal of Educational and Instructional Studies in the World, vol. 2, no. 2. (2012).

[16] F. Duwiyanti and M. Ardhiansyah, "Sistem Pendukung Keputusan Pemilihan Guru Terbaik di SMK Pustek Serpong”, ijeste, vol. 2, no. 1, pp. 45 - 67, Jun. 2019. 